\title{
Disturbing Effects of Chronic Low-dose 4-Nonylphenol exposing on Gonadal Weight and Reproductive Outcome over One-generation
}

\author{
Sunyeong Cha ${ }^{1}$, Jeong Won Baek ${ }^{1}$, Hye Jin $\mathbf{J i}^{1}$, Jun Hee Choi ${ }^{1}$, Chaelim Kim ${ }^{1}$, Min Young Lee ${ }^{1}$, \\ Yeon Jeong Hwang ${ }^{1}$, Eunhyeok Yang${ }^{1}$, Sung-Ho Lee ${ }^{2}$, Hyo-il Jung ${ }^{3}$ and ${ }^{\dagger}$ Yong-Pil Cheon $^{1}$ \\ ${ }^{I}$ Division of Developmental Biology and Physiology, School of Biological Sciences and Chemistry, \\ Sungshin University, Seoul 02844, Korea \\ ${ }^{2}$ Department of Lifesicence, Sangmyung University, Soeul 03016, Korea \\ ${ }^{3}$ School of Mechanical Engineering, Yonsei University, Seoul 03722, Korea
}

\begin{abstract}
Nonylphenol (NP) is a surfactant that is a well-known and widespread estrogenic endocrine disrupting chemical (EDC). Although it has been known that the affinity of NP to ERs is low, it has been suggested that low-dose NP has toxicity. In the present study, the endocrine disrupting effects on reproduction, and the weight of gonads, epididymis, and uterus were evaluated with the chronic lower-dose NP exposing. This study was designed by following the OECD test guideline 443 and subjected to a complete necropsy. In male, NP had an effect on the weight of the testis and epididymis in both $\mathrm{F}_{0}$ and $F_{1}$. In females, NP decreased the weight of ovary and uterus in $F_{0}$ but not in pre-pubertal $F_{1}$ pubs. Fertility of male and female in $\mathrm{F}_{0}$ or $\mathrm{F}_{1}$ was no related with NP administration. The number of caudal-epididymal sperm by body weight (BW) was not different between groups in both $\mathrm{F}_{0}$ and $\mathrm{F}_{1}$. Besides, the difference of the sperm number between generations was not detected. The number of ovulated oocytes was similar between groups in $\mathrm{F}_{0}$, but significantly decreased in NP 50 group of $\mathrm{F}_{1}$. The litter size and sex ratios of offspring in $\mathrm{F}_{1}$ and $\mathrm{F}_{2}$ were not different. The accumulated mating rate and gestation period were not affected by the NP administration. Those results shows that chronic lower-dose NP administration has an effect of endocrine disruptor on the weight of gonads and epididymis of $F_{0}$ and $F_{1}$ but not in reproduction. Based on the results, it is suggested that chronic lower-dose NP exposing causes endocrine disruption in the weight of gonad and epididymis but not in the reproductive ability of next generations.
\end{abstract}

Key words : Chronic low-dose nonylphenol, Endocrine disrupting, Nonylphenol, Reproduction, Sperm count

\section{INTRODUCTION}

Endocrine disrupting chemical (EDC) is prevalent in the environment (Fox et al., 2004; Choi et al., 2016; Monneret, 2016), and animals can be exposed to EDC via their occuations, ingestion of food (Fox et al., 2004), dust and water (Rudel et al., 2009), and skin (Davey et al., 2007; Kabir et al., 2015). Those EDCs can affect human and wildlife animal reproductive performance (Culty et al., 2008; Phillips et al., 2008; Robins et al., 2011). Based on the dogma of pharmacology, the dose makes the poison (Vandenberg et al., 2012), and most of the studies about EDC have been focused in the toxicological concepts for decades (Swedenborg, 2009; Vandenberg et al., 2012). However, some

\footnotetext{
Manuscript received April 3, 2017, Received in revised form April 5, 2017, Accepted April 7, 2017

$\dagger$ Corresponding Author : Yong-Pil Choen, Division of Developmental Biology and Physiology, Department of Biotechnology, Sungshin University, Seoul 02844, Korea. Tel: +82-2-920-7639, Fax: +82-2-920-2736, E-mail: ypcheon@sungshin.ac.kr

This is an Open Access article distributed under the terms of the Creative Commons Attribution Non-Commercial License (http:// creativecommons.org/licenses/by-nc/3.0) which permits unrestricted non-commercial use, distribution, and reproduction in any medium, provided the original work is properly cited.
} 
researches have suggested that EDCs can act in the nanomolar to micromolar range or at picomolar levels like in natural hormones and can damage human and/or animal health. Besides, research is needed to understand whether low-dose responses are lined to adverse effects and mechanisms. Therefore, it becomes more and more important to know the possible effects of endocrine disrupting chemicals (EDCs) in physiological process (Kawaguchi et al., 2015; Mantovani, 2017).

The environmental xenobiotics can get potential to hormonal signaling disruptors by itself or their metabolites (Bonde et al., 2017). So far, the information about metabolized EDCs and specific exposure is insufficient. The degradation products of nonlyphenol ethoxylate (NPE) included 4-nonylphenol (NP), nonylphenol ethoxylate (NPIEO), nonylphenol diethoxylate (NP2EO), nonylphenol triehoxylates (NP1-3EO), nonlyphenoxyacetic acid (NP1EC), and nonylphenolxyacetic acid (NP2EC) (Sheahan et al., 2002; Swartz et al., 2006). Those belong to aklyphenols and are considered to have weak estrogenic activities in vivo and in vitro testing system (Bøgh et al., 2001; Watanabe et al., 2004; Maruya et al., 2012). It is known that NP binds to estrogen receptors and mimics the work of $17 \beta$-estradiol, although the affinity of NP for ESR1 has less magnitude than the affinity of 17ß-estradiol (Preuss et al., 2006; Bonefeld-Jørgensen et al., 2007; Soares et al., 2008).

EDCs have been known to produce adversely embryonic development, reproductive, neurological and immune effects in animal (Diamanti-Kandarakis et al., 2009). The possible toxicity of EDC depends on the dosage, duration, and the expose of life stage. Maternal exposure of EDCs can be negatively influenced on parents as well as $F_{1}$ generation (Bøgh et al., 2001). The NP (100-300 mg/kg/day for 30 days; Aly et al., 2012) during perinatal period or adulthood (100 mg/kg; Duan et al., 2017) has a negative effect on spermatogenesis and sperm quality in vivo fertility. Neonatal expose delay testes decent and adult expose affect particularly on spermatogenesis $(250 \mathrm{mg} / \mathrm{kg}$, Dejager et al., 1999a; 400 mg/kg, Dejager et al., 1999b; 8 mg/ kg, Odum $\&$ Ashby, 2000). It also can give an effect on other organs and functions such as learning and memory (Jie et al., 2013; Kawaguchi et al., 2015). By such experimental results and warning of ECDs, REACH (registration, evaluation, authorization and restriction of chemicals), European chemical agency (ECHA), and Significant New Use Rules (SNURS) has restricted the percentage of NP as $0.1 \%$.

Recently the possible effects of low dose EDCs were continuously suggested. Low-dose NP has effects in both cell and in vivo levels (Melnick et al., 2002; Xu et al., 2017). Yu et al (2011) explored that $100 \mu \mathrm{g} / \mathrm{kg}$ NP can modulate the production of progesterone in rat granulosa cells. $0.5 \mathrm{mg} / \mathrm{kg}$ NP slightly impairs special learning performance in male and female rat (Kawaguchi et al., 2015). In this study, we employed the OECD test guideline 443 "the expended one-generation reproductive toxicity study" to evaluate the possible adverse effects of chronic lowdose effects on the body weight, reproductive organ weight, and reproduction.

\section{MATERIALS \& METHODS}

\section{Experimental animals}

All experimental animal(s) was studied according to the Guide for the Care and Use of Laboratory Animals published by the national Institutes of Health and to the Test Guideline 443 suggested by OECD and under the Experimental Animals Committee of Sungshin University. Animals (CD-1 mice) were maintained under standard condition; temperature $\left(20-24^{\circ} \mathrm{C}\right)$, humidity (45-55\%), and light (14 hr light/ $10 \mathrm{hr}$ dark) conditions. They were fed free phytoestrogen diet (2018 Teklad global 18\% protein rodent diets; ENVIGO, Madison, WI, USA) and water ad libitum using glass bottles. To get $\mathrm{F}_{0}$ generation, the mice fed phytoestrogen free diet were used. Their offspring with normal estrous cycle was chosen as $\mathrm{F}_{0}$. The pubs were weaned at 21 post-natal days. 


\section{Chemical treatments}

Nonylphenol (Sigma-Aldrich, Cat \# 46018, CAS \# 8485215-3) was selected as an endocrine disrupting chemical and used at two concentration based on previous report (Kyselova et al., 2003), $50 \mu \mathrm{g} / \mathrm{L}$ and $500 \mu \mathrm{g} / \mathrm{L}$ in drinking water. The chemical stock solution was prepared in purified water and stored at $-20^{\circ} \mathrm{C}$. Treatment was proceded according on schedule suggested by OECD test guideline (TG) 443. Briefly, paternal generation (F0) were administered in drinking water during 10weeks (pre-mating; 2 weeks, mating; 2 weeks, post mating included pregnancy and lactation; 6 weeks) and then were anatomized for organ sampling (Fig. 1). $F_{1}$ were administered for experiment of organ sampling during postnatal day 51 (male) and about postnatal day 28 (female, after vagina opening 3 days).

\section{Body and organ weight}

The control and experimental groups of the same sex were sacrificed at the same time. The males and females $\mathrm{F}_{0}$ were sacrificed at end of chemical treatment periods for 10 weeks, and the reproductive organ (testes and epididymis in males; ovary and uterus in females) were excised out and weighed individually. Relative organs weight was cal- culated based on organ to body weight. In $F_{1}$ mice, they were sacrificed at postnatal day 51(male) and postnatal day 28 (female, after vagina opening 3 days) and examined as $\mathrm{F}_{0}$.

\section{Oocyte and sperm counting}

To evaluate the number of ovulated oocytes, $F_{0}$ and $F_{1}$ generation female (6 weeks old) were superovulated by injection of 2.5 IU pregnant mare serum gonadotropin (PMSG, sigma) followed $48 \mathrm{hr}$ later by injection $2.5 \mathrm{IU}$ of human chronic gonadotropin (hCG, sigma). After $15 \mathrm{hr}$, the female mice were sacrificed and oocytes were collected from ampulla. The number of sperm was counted with Makler counter chamber (Sefi Medical Instruments LTD, Santa Ana, CA, USA). The caudal sperm collection was followed the method for mouse in vitro fertilization (Hogan et al., 1994).

\section{Statistical analysis}

The results represent means \pm SED. The data were analyzed using one-way analysis of variance (ANOVA) and $t$ test between control and experimental group. In all cases, values of $P<0.05$ were deemed to indicate statistical significance.

\section{Dosing}

\begin{tabular}{|c|c|c|c|c|c|}
\hline & Pre-mating & Mating & \multicolumn{2}{|c|}{ Post-mating } & \\
\hline Pठ̊ & 2 weeks & 2 weeks & \multicolumn{2}{|c|}{6 weeks } & \\
\hline \multirow[t]{2}{*}{ Po } & 2 weeks & 2 weeks & Pregnancy & Lactation & \\
\hline & & $\mathrm{F}_{1} / \mathrm{F}_{2}$ & In-utero development & Pre-weaning & Post-weaning \\
\hline
\end{tabular}

Fig. 1. Scheme to assess the one-generation reproductive toxicity study. 8-week-old mice which were offspring of phytoestrogen free food-fed parents were examined their estrus cycle with vaginal smearing methods for 2 weeks. The normal female mice attend mating. 


\section{RESULT}

\section{Reproductive organ weight}

In male mice, the weights of testis and epididymis were measured as mentioned in Materials and Methods. The weight of testis of $F_{0}$ male significantly decreased in NP 50 group but not in NP 500 group (Fig. 2). The weight of epididymis significantly increased in NP 50 group but not in NP 500 group (Fig. 2). In $F_{1}$ male, which were treated from gamete to until sampling, the weights of testis and epididymis significantly decreased and increased in NP 50 groups, respectively (Fig. 2).

In $\mathrm{F}_{0}$ female mice, that were administered with NP as de-
A
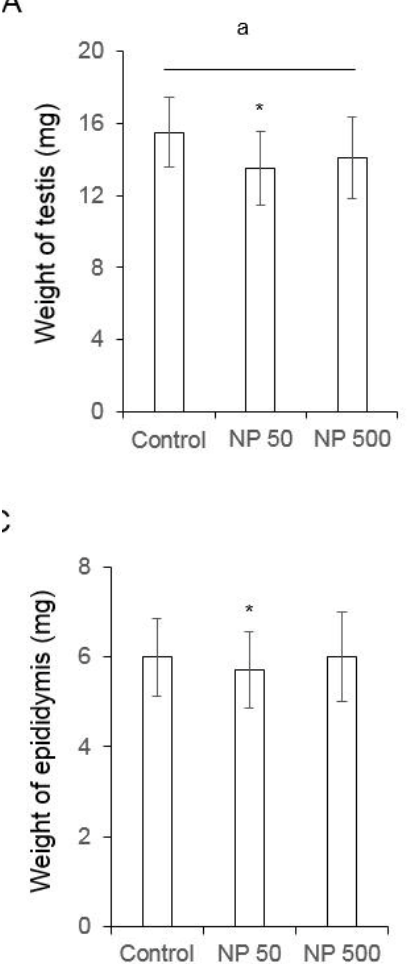

B

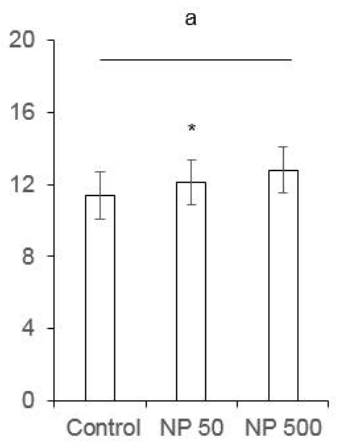

D

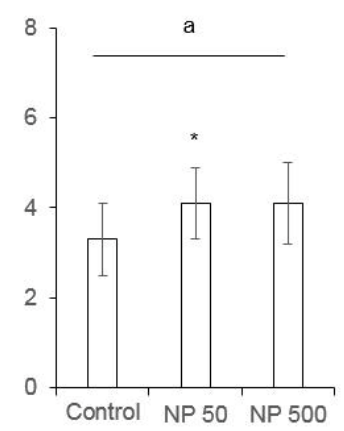

Fig. 2. The effects of nonylphenol (NP) on the weight of testis ( $A$ and $B$ ) and epididymis $(C$ and $D)$ in $F_{0}$ (A, C) and $F_{1}(B, D)$. NP was administered as shown Fig. 1. $F_{0}$ and $F_{1}$ males were sacrificed at 18 20 weeks and 7-8 weeks after birth, respectively. a: $P<0.05$ (One way ANOVA). *: $P<0.05$ ( $t$-test, control vs. NPs). picted in Fig. 1, the ovarian weight significantly increased in NP 50 group but not in NP 500 group. However, the weight of ovary was not changed in $F_{1}$ (Fig. 3). The weight of uterus in $\mathrm{F}_{0}$ female was significantly increased NP 50 and NP 500 groups in concentration-dependent manner. However, in $\mathrm{F}_{1}$ female, which were treated from gamete to sampling (4-5 weeks old), the weight of uterus was not changed (Fig. 3).

\section{Number of caudal sperm and ovulated oocytes}

The number of cauda epididymal sperm per body weight was same in controls of $F_{0}$ and $F_{1}$ males. Also, in NP 50 and NP 500 groups, it was not changed by generation and groups (Fig. 4). The numbers of ovulated oocytes in $F_{0}$ were not changed by administration of 50 and $500 \mu \mathrm{g} / \mathrm{L}$ NP (Fig. 5A). In $F_{1}$ generation, the number of ovulated oocytes was significantly decrease in NP 50 group but not
A
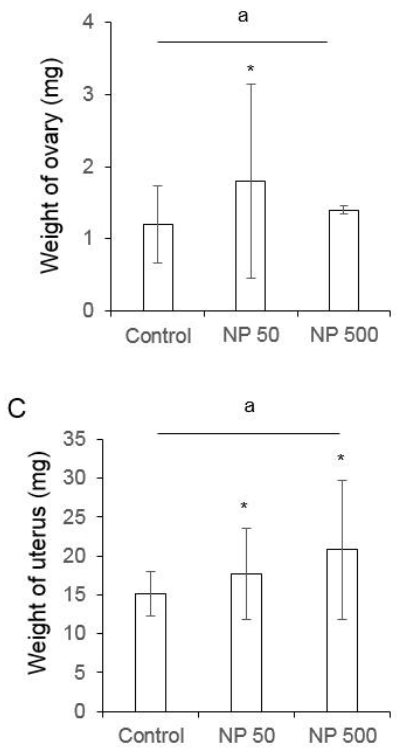

B

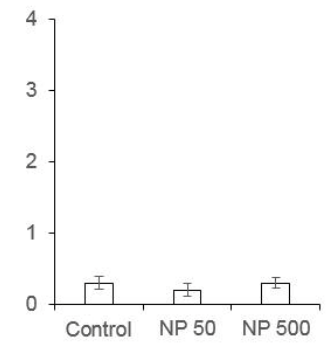

D

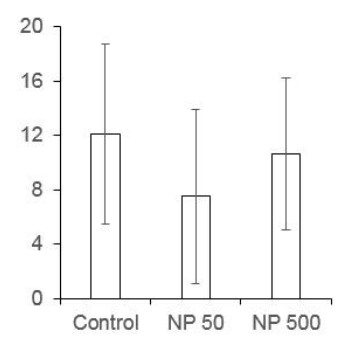

Fig. 3. The effects of nonylphenol (NP) on the weight of ovary $\left(F_{0}, A ; F_{1}, B\right)$ and uterus $\left(F_{0}, C ; F_{1}, D\right)$. NP was administered as shown Fig. 1. $\mathrm{F}_{0}$ and $\mathrm{F}_{1}$ females were sacrificed at $18-20$ weeks and 4-5 weeks after birth, respectively. a: $P<0.05$ (One way ANOVA). *: $P<0.05$ ( $t$-test, control vs. NPs). 
in NP 500 group (Fig. 5B). However, the decrease or increase were not detected in $\mathrm{F}_{2}$ female (data not shown).

\section{Effect of nonylphenol on reproductive outcome}

For first 2 weeks we treated low-dose NP, and kept next 2 weeks the males and females in the same cage to mate.

There was no significant difference in litter size in both

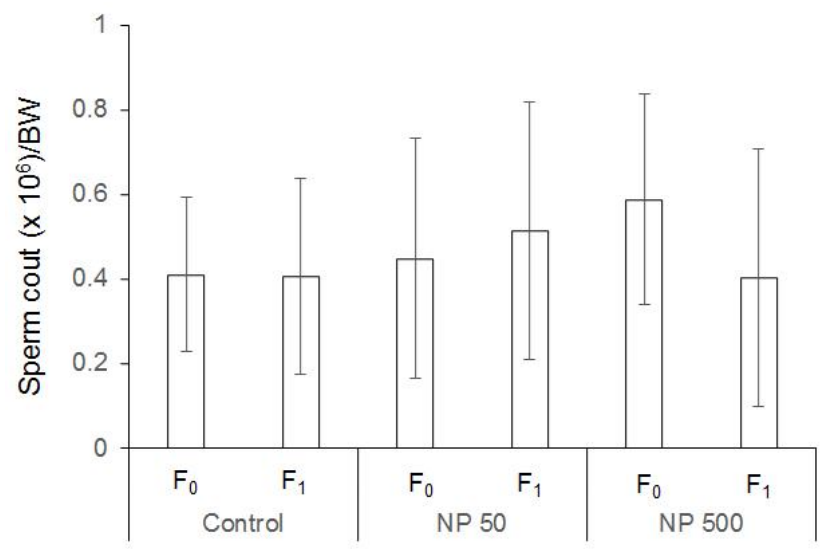

Fig. 4. The ratio of sperm count to body weight in caudal epididymis. The caudal epididymis was isolated and extracted the sperms by squeeze and mincing. The number of sperms were counted with Makler chamber.

A

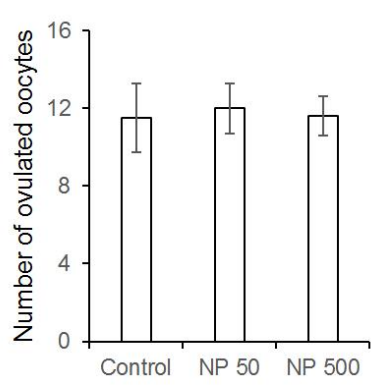

B

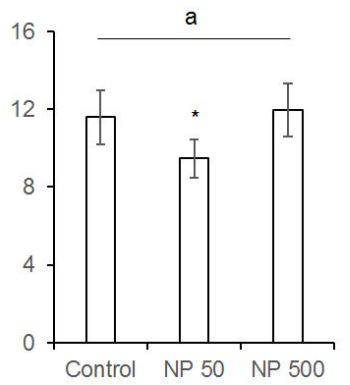

Fig. 5. The effects of nonylphenol (NP) on the ovulation of $F_{\mathbf{0}}(\mathbf{A})$, and $\mathbf{F}_{\mathbf{1}}$ (B). Nonlyphnol (NP) was administered as shown Fig. 1 and ovulation was induced with gonadotrophins. The ovulated oocytes were collected from ampulla of oviduct at $15 \mathrm{hr}$ after hCG injection. a: $P<0.05$ (One way ANOVA). *: $P<0.05$ ( $t$-test, control vs. NPs).
$F_{1}$ and $F_{2}$ generation (Table 1). The sex ratios of pubs were not changed by the expose of NP in all groups of $F_{1}$ and $F_{2}$ (Fig. 6). The accumulated mating rate of $\mathrm{F}_{0}$ was not different between groups. The accumulated mating rate was $100 \%$ in all groups. The accumulated mating rate was also $100 \%$ in all groups of $F_{1}$ generation (Fig. 7A). In addition, the accumulated rates of successful delivery were not also affected by NP in all groups (Fig. 7B). The gestation length in $F_{0}$ and $F_{1}$ was also not changed by the administered NP (Fig. 8).

Table 1. Effect of nonylphenol on litter size over onegeneration

\begin{tabular}{ccccc}
\hline \hline Generation & Group & $\begin{array}{c}\text { No. } \\
\text { female }\end{array}$ & $\begin{array}{c}\text { No. } \\
\text { delivery }\end{array}$ & Litter size \\
\hline \multirow{3}{*}{$\mathrm{F}_{1}$} & Control & 20 & 20 & $11.5 \pm 1.84$ \\
& NP 50 & 20 & 20 & $12.0 \pm 3.29$ \\
& NP 500 & 20 & 20 & $10.8 \pm 5.34$ \\
\hline \multirow{3}{*}{$F_{2}$} & Control & 35 & 35 & $12.0 \pm 6.75$ \\
& NP 50 & 40 & 40 & $11.8 \pm 6.18$ \\
& NP 500 & 35 & 35 & $12.0 \pm 3.85$ \\
\hline
\end{tabular}

A

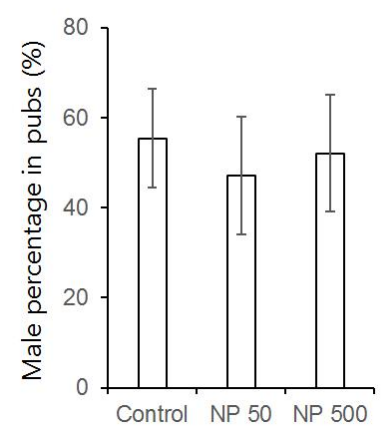

B

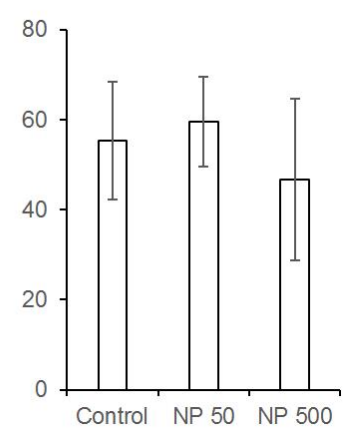

Fig. 6. The sex ratios in $F_{1}(A)$ and $F_{2}(B)$ pubs. The $F_{0}$ and $F_{1}$ parents were administered with nonylphenol (NP) containing water as depicted in Fig. 1. 10 weeks old mice were attended mating. NPs did not effect on sex ratios in both $F_{1}$ and $F_{2}$. 

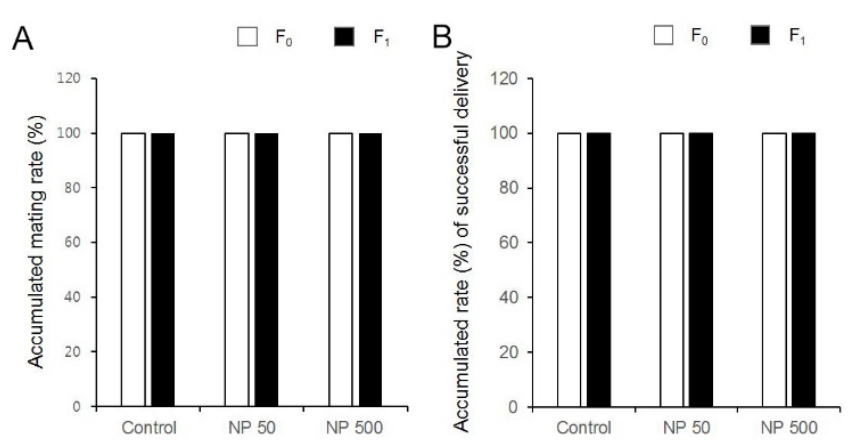

Fig. 7. The effects of nonylphenol (NP) on mating rate (A) and successful delivery rate (B). Nonlyphnol (NP) was administered according to the phytoestrogen free generation $F_{0}$ according to the OECD Test Guide line 443. Accumulated mating rates and the accumulated rate of successful delivery were not affected by NP administration in both $\mathrm{F}_{0}$ and $\mathrm{F}_{1}$. All pregnant mice delivered successfully.

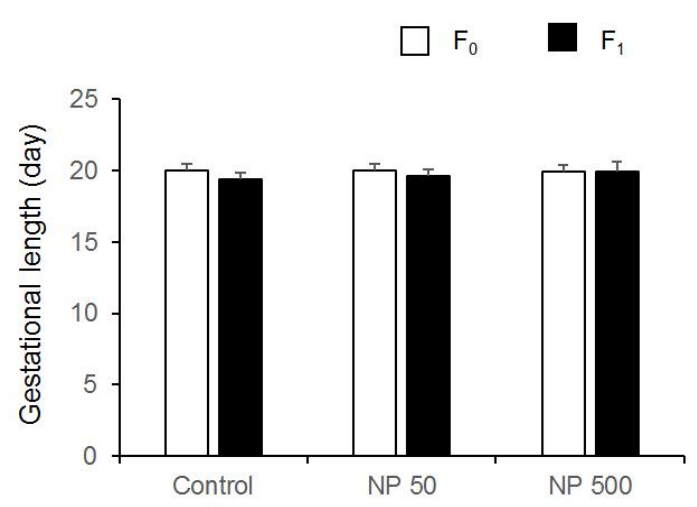

Fig. 8. The effects of nonylphenol (NP) on gestational length in $F_{0}$ and $F_{1}$. NP was administered as shown Fig. 1. Copulation plugs were checked every day morning. To keep the strict time for mating, the female which did not have copulation plug, were separated at morning and caging again with male at 5:00 $\mathrm{pm}$. There was no difference in gestational periods.

\section{DISCUSSION}

Laboratory studies on animals have demonstrated adverse effects of NP, such as on reproduction, development, neurotoxicity and inflammation (Jie et al., 2013; Yücedağ et al., 2015). The responsibility of organisms are various by the exposing dose and duration, and the exposing time of life cycle (Patisaul \& Adewale, 2009; Solecki et al., 2017). One of the interesting things is that as anathema to the toxicological principle, the dose response of many hormones and EDCs appears to be nonmonotonic (Patisaul \& Adewale, 2009). Lee (1998) suggested that NP (8 mg/ kg/ day, ip) administered from pnd 1 to 10 results in the decreased weight of reproductive organs including epididymis. However, Odum and Ashby (2000) does not conform to the results with Alpk (Wistar derived) rats. Such doseindependent results can be found in gene expression patterns. The genes are expressed in a dose-dependent manner at $0.5-50 \mu \mathrm{g} / \mathrm{kg}$ but not in $50 \mathrm{mg} / \mathrm{kg}$ NP (Watanabe et al., 2004). Consistences with those reports, our results show that the effects of NPs did not show dose dependent responsibility. The weight of testis and epididymis decreased or increased on only NP 50 group of $F_{0}$ and $F_{1}$, respectively. In ovary, the weight was increased only at 50 $\mu \mathrm{g} / \mathrm{L} \mathrm{NP}$ in $\mathrm{F}_{0}$.

Estradiol stimulates the proliferation of immature and adult uterine cells and increases the weight (Black and Goode, 1980; Maier et al., 1985). The relative binding affinity of NP to estrogen receptors is $0.035-0.037 \%$ and the mean $\mathrm{IC}_{50}$ is $4.00 \times 10^{-7} \pm 0.10 \times 10^{-7}-4.40 \times 10^{-7} \pm 0.40 \times 10^{-7}$ (Blair et al., 2000). In the uterus, high dose NP $(50 \mathrm{mg} / \mathrm{kg})$ has similar effect on most of the genes that are activated by estradiol, and low-dose NP $(0.5$ and $5 \mathrm{mg} / \mathrm{kg})$ has little effect on the genes that are activated by estradiol (Watanabe et al., 2004). In adults, daily dosing 0.5 and $5 \mathrm{mg} / \mathrm{kg}$ $\mathrm{NP}$ are equal to 15 and $150 \mu \mathrm{g} \mathrm{NP}$, respectively. On the other hand, 50 and $500 \mu \mathrm{g} / \mathrm{L} \mathrm{NP}$ in daily drinking water (4$7 \mathrm{~mL} /$ day/adult) are equivalent to 0.275 and $2.75 \mu \mathrm{g} \mathrm{NP}$, respectively. Interestingly the uterine weight of parent generation was increased in a concentration-dependent manner. However, in pre-pubertal $F_{1}$ female, the uterine weights were not different between groups. This means that lower dose than $15 \mu \mathrm{g} /$ day can effect on the reproductive organs 
in a nonmonotonic manner, although NP is 100,000 times less affinity to ERs than estradiol.

Studies show the dimorphic characteristics in males and females to EDCs and suggested female and male germ cells have different susceptibilities to ECD (Anway et al., 2005; Clifton, 2010). Such dimorphism is also supported by our results, as in male mice, the weights of testis and epididymis were affected only by $50 \mu \mathrm{g} / \mathrm{L}$ in both $\mathrm{F}_{0}$ and $F_{1}$. However in female, the ovary and uterus were affected only in $\mathrm{F}_{0}$. Lower-dose NP did not effect on the weight of ovary or uterus in the pre-pubertal female $F_{1}$ mice, even though they were exposed from germ cell stage. Parental generation and $F_{1}$ males treated with 50 and $500 \mu \mathrm{g} / \mathrm{L}$ had similar sperm counts compared with control but not in the number of ovulated oocytes. This means that as expected, the susceptibility to EDC effects of NP changed depending on sex-related endocrine regulation.

It has been suggested that exposing to prenatal and early postnatal EDC might be the causal path of male reproductive disorder such as cryptorchidism, hypospadias, low sperm count and testicular cancer (Bøgh et al., 2001; Rissman \& Adli, 2014; Bonde et al., 2017). In addition, altering the epigenic programing of the germ line is observed in the male administered EDCs during fetal gonadal sex determination and such altered epigenic characters are inherited to the subsequent generations (Guerrero-Bosagna $\&$ Skinner, 2014). Spermatogenesis in adult male rat that are exposed with NP $(100 \mathrm{mg} / \mathrm{kg})$ is affected and the number of sperm decreased (De Jager et al., 1999). However, in meta-analysis, a total of 33 papers provide 89 risk estimates on which there is no strong support for a global effect as a whole or on any specific outcome in male reproduction disorders following prenatal and postnatal exposure (Bonde et al., 2017). Interestingly in this study, the responsibility of testis and epididymis were different between NP 50 and NP 500 groups but the number of offspring, sex ratio of pubs, and accumulated mating rate were not changed. This means that the responding patterns to lower-dose NP in reproduction are different by the character of organs.

Kyselova and colleagues (2003) examined with the same doses except the exposed duration (4 week in CD-1 mice ( 8 wks old)). Based on the results of Kyselova et al (2003), the detrimental effects on the fertility of sperm of $F_{1}$ which were exposed to NP according to OECD TG 443 could be suspected. Kyselova et al (2003) evaluated the detrimental effect on acrosomal stability. However, the $F_{1}$ generation mice had similar responsibility to the NPs in accumulated mating rates and gestational length compared with the control and NP groups. The litter size and sex ratio in $F_{1}$ and $F_{2}$ generation were also not different between groups and generations. However, interestingly we did not find any detrimental effects on male fertility. The number of pubs and their sex ratio in $\mathrm{F}_{0}$ and $\mathrm{F}_{1}$ generation were similar between groups and generation. Such difference may be the result of the difference in exposing duration.

The WHO defines the endocrine disruptors as an exogenous substance or mixture that alters the function(s) of the endocrine system and consequently causes adverse effects in an intact organism, or its progeny, or population. The adverse effect refers to "a change in morphology, physiology, growth, reproduction, development or lifespan of an organism which results in impairment of functional capacity or impairment of capacity to compensate for additional stress or increased susceptibility to the harmful effects of other environmental influences" (Solecki et al., 2017). Kyselova et al (2003) suggest that exposing NP (50 and $500 \mu \mathrm{g} / \mathrm{L}$ ) to 2 months old male for 4 weeks has multigenerational effect on selective reproductive organ. From our results it is clear that lower-dose NP has characters of EDC in male and female of $F_{0}$ and $F_{1}$ generation. However, the chronic exposing of lower-dose NP has no detrimental effect on fertility of the subsequent generation. 


\section{ACKNOWLEDGEMENT}

We thank to Jiyoung Lee for assistance. This study was supported by a grant of National Research Foundation of Korea (NRF-2015M3A9D7067365).

\section{REFERENCES}

Aly HA, Doménech O, Banjar ZM (2012) Effect of nonylphenol on male reproduction; Analysis of rat epididymal biochemical markers and antioxidant defense enzymes. Toxicol Appl Pharmacol 261:134-141.

Anway MD, Cupp AS, Uzumcu M, Skinner MK (2005) Epigenetic transgenerational actions of endocrine disruptors and male fertility. Science 308:1466-1469.

Black LJ, Goode RL (1980) Uterine bioassay of tamoxifen, trioxifene and a new estrogen antagonist (LY117018) in rats and mice. Life Sci 26:1453-1458.

Blair RM, Fang H, Branham WS, Hass BS, Dial SL, Moland CL, Tong W, Shi L, Perkins R, Sheehan DM (2000) The estrogen receptor relative binding affinities of 188 natural and xenochemicals: structural diversity of lignads. Toxicol Sci 54:138-153.

Bøgh IB, Christensen P, Dantzer V, Groot M, Thøfner IC, Rasmussen RK, Schmidt M, Greve T (2001) Endocrine disrupting compounds: effect of octylphenol on reproduction over three generation. Theriogenology 55: 131150.

Bonde JP, Flachs EM, Rimborg S, Glazer CH, Giwercman A, Ramlau-Hansen CH, Hougaard KS, Høyer BB, Hærvig KK, Petersen SB, Pylander L, Specht IO, Toft G, Bráuner EV (2017) The epidemiologic evidence linking prenatal and postnatal exposure to endocrine disrupting chemicals with male reproductive disorders: a systemic review and meta-analysis. Hum Reprod Update 23:104-125.

Bonefeld-Jørgensen EC, Long M, Hofmeister MV, Vinggaard AM (2007) Endocrine-disrupting potential fo bi- sphenol A, bisphenol A dimethacrylate, 4-n-nonylphenol, and 4-n-octylphenol in vitro: New data and a brief review. Environ Health Perspect 115:69-76.

Choi JS, Park JH, Kim Y, Kim JK, Jung ST, Han B (2016) Removal of nonylphenol from industrial sludge by using an electron beam. J Korean Phys Soc 69:1029-1034.

Clifton VL (2010) Review: Sex and the human placenta: mediating differential strategies of fetal growth and survival. Placenta 31(Supple): S33-539.

Culty M, Thuillier R, Li W, Wang Y, Martinez-Arguelles DB, Benjamin CG, Triantafilou KM, Zirkin BR, Papadopoulos V (2008) In utero exposure to di-(2-ethylhexyl) phthalate exerts both short-term and long-lasting suppressive effects on testosterone production in the rat. Biol Reprod 78:1018-1028.

Davey JC, Bodwell JE, Gosse JA, Hamilton JW (2007) Arsenic as an endocrine disruptor: Effects of arsenic on estrogen receptor-mediated gene expression in vivo and in cell culture. Toxicol Sci 98:75-86.

De Jager C, Bornman MS, Oosthuizen MC II (1999) The effect of p-nonylphenol on the fertility potential of male rats after gestational, lactational and direct exposure. Andrologia 31:107-113.

Dejager C Bornman MS, Oosthuizen MC (1999b) Effect of p-nonylphenol on fertility potential in male rats after gestational, lactational and direct exposure. Andrologia $31: 107-113$

Dejager C Bornman MS, Wandrag S, vea der Horst G (1999a) Effect of p-nonylphenol, and environmental toxicant with oestrogenic properties, on fertility potential in adult male rats. Andrologia 31:99-106.

Diamanti-Kandarakis E, Bourguignon JP, Giudice LC, Hauser R, Prins GS, Soto AM, Zoeller RT, Gore AC (2009) Endocrine-disrupting chemicals: an endocrine society scientific statement. Endocr Rev 30:293-342.

Duan P, Hu C, Butier HJ, Quan C, Chen W, Huang W, Tang S, Zhou W, Yuan M, shi Y, Martin FL, Yang K (2017) 4-Nonylphenol induces disruption of spermato- 
genesis associated with oxidative stress-related apoptosis by targeting p53-Bcl-2/Bax-Fas/FasL signaling. Environ Toxicol 32:739-753.

Fox JE, Starcevic M, Jones PE, Burow ME, McLachlan JA (2004) Phytoestogen signaling and symbiotic gen activation are disrupted by endocrine-disrupting chemicals. Environ Health Perspect 112:672-677.

Guerrero-Bosagna C, Skinner MK (2014) Environmentally induced epigenetic transgenerational inheritance of male infertility. Curr Opin Genet Dev 26:79-88.

Hogan B, Beddington R, Costamtini F, Lacy E (1994) Section C; Recovery, culture, and transfer of embryos and germ cells. In: Manipulating the Mouse Embryo. $2^{\text {nd }} e d$. Cold Spring Harbor Laboratory Press, New York. Pp 127-188.

Jie X, Jianmei L, Zheng F, Lei G, Biao Z, Jie Y (2013) Neurotoxic effects of nonylphenol: a review. Wien Klin Wochenschr 125:61-70.

Kabir ER, Rahman MS, Rahman I (2015) A review on endocrine disruptors and their possible impacts on human helath. Environ Toxicol Pharmacol 40:241-258.

Kawaguchi S, Kuwahara R, Kohara Y, Uchida Y, Oku Y, Yamashita K (2015) Oral exposure to low-dose of nonylphenol impairs memory performance in SpragueDawley rats. J Toxicol Sci 40:43-53.

Kyselova V, Peknicova J, Buckiova D, Boubelik M (2003) Effects of p-nonylphenol and resveratrol on body and organ weight and in vivo fertility of outbred CD-1 mice. Reprod Biol Endocrinol 1:30-39.

Lee PC (1998) Disruption of male reproductive tract development by administration of the xenoestrogen, nonylphenol, to male newborn rats. Endocrine 9:105-111.

Maier DB, Newbold RR. McLachlan JA (1985) Prenatal diethylstilbestrol exposure alters murine uterine responses to prepubertal estrogen stimulation. Endocrinology 116:1878-1886.

Mantovani A (2017) Why research on endocrine disrupting chemicals is still worthwhile. Ann 1st Super Sania
$53: 1-2$.

Maruya KA, Vidal-Dorsch DE, Bay SM, Kwon JW, Xia K, Armbrust KL (2012) Organic contaminants of emerging concern in sediments and flatfish collected near outfalls discharging treated wastewater effluent to the Southern California Bight. Environ Toxicol Chem 31: 2683-2688.

Melnick R, Lucier G, Wolfe M, Hall R, Stancel G, Prins G, Gallo M, Reuhl K, Ho SM, Borwn T, Moore J, Leakey J, Haseman J, Kohn M (2002) Summary of the national toxicology promgram's report of the endocrine disruptors low-dose peer review. Environ Health Perspect 110:427-431.

Monneret C (2016) What is an endocrine disruptor? Academy of sciences. www.acadpharm.org/dos_public/TEXTE ACADSCIv2.pdf

Odum J, Ashby J (2000) Neonatal exposure of male rats to nonylphenol has no effect on the reproductive tract. Toxicol Science 56:400-404.

Patisaul HB, Adewale HB (2009) Long-term effects of environmental endocrine disruptors on reproductive physiology and behavior. Front Behav Neurosci 3:10.

Phillips KP, Tanphaichitr N (2008) Human exposure to endocrine disrupters and semen quality. J Toxicol Environ Health B Crit Rev 11:188-220.

Preuss TG, Gehrhardt J, Schirmer K, Coors A, Rubach M, Russ A, Jones PD (2006) Nonylphenol isomers differ in estrogenic activity. Environ Sci Technol 40:51475153 .

Rissman EF, Adli M (2014) Transgenerational epigenetic inheritance: focus on endocrine disrupting compounds. Endocrinology 155:2770-2780.

Robins JC, Marsit CJ, Padbury JF, Sharma SS (2011) Endocrine disruptors, environmental oxygen, epigenetics and pregnancy. Front Biosci (Elite Ed)3:690-700.

Rudel RA, Rerovivh LJ (2009) Endocrine disrupting chemicals in indoor and outdoor air. Atmos Environ. 43:170-181 
Sheahan DA, Brighty GC. Daniel M, Kirby SJ, Hurst MR, Kennedy J, Morris S, Routledge EJ, Sumpter JP, Waldock MJ (2002) Estrogenic activity measured in a sewage treatment works treated industrial inputs containing high concnetrations of alkylphenolic compounds - a case study. Environment Toxicol Chem 21:507-514.

Soares A, Guieysse B, Jefferson B, Cartmell E, Lester JN (2008) Nonylphenol in the environment: a critical review on occurrence, fate, toxicity and treatment in wastewaters. Environ Int 34:1033-1049.

Solecki R, Kortenkamp A, Bergman A, Chahoud I, Degen GH, Dietrich D, Greim H, Hakansson H, Hass U, Husoy T, Jacobs M, Jobling S, Mantovani A, MarxStoelting P, Piersman A, Ritz V, Slama R, Stahlmann R, van den Berg M, Zoeller RT, Boobis AR (2017) Scientific principles for the identification of endocrinedisrupting chemicals: a consensus statement. Arch Toxicol 91:1001-1006.

Swartz CH, Reddy S, Benotti MJ, Yin H, Barber LB, Brownawell BJ, Rudel RA (2006) Steroid estrogens, nonylphenol ethoxylate metabolites, and other wastewater contaminants in groundwater affected by a residential septic system on cape cod, MA. Environ Sci
Technol 40:4894-4902.

Swedenborg E, Ruegg J, Makela S, Pongrats I (2009) Endocrine disruptive chemicals: mechanisms of action and involvement in metabolic disorders. J Mol Endocrinol. 43:1-10.

Vandenberg LN, Colborn T, Hayes TB, Heindel JJ, Jacobs Jr DR, Lee DH, Shioda T, Soto AM, vom Saal FS, Welshons WV, Zoeller RT, Myers JP (2012) Hormones and endocrine-disrupting chemicals: low-dose effects and nonmonotonic dose responses. Endo Rev 33:378455.

Watanabe H, Suzuki A, Goto M, Lubahn DB, Handa H, Iguchi T (2004) Tissue-specific estrogenic and nonestrogenic effects of a xenoestrogen, nonylphenol. J Mol Endocrinol 33:243-252.

Xu Z, Liu J, Wu X, Huang B, Pan X (2017) Nonmonotonic responses to low doses of xenoestrogens: a review. Environ Res 155:199-207.

Yu PL, Lin HW, Wang SW, Wang PS (2011) Effects of nonylphenol on the production of progesterone on the rats granulosa cells. J Cell Biochem 112:2627-2636.

Yücedağ F, Okur E, Uğuz C, Zemheri F, Kuzu S, Ayçiçek A, Kahveci O (2015) The effects of nonylphenol on hearing in rats. Int Adv Otol 10:76-79. 